\title{
Audit rotation and audit fee determination policy on audit quality with lowballing audit practice as the intervening variable
}

\author{
Anisa Listya $^{1 *}$, Muhammad Ichsan Siregar ${ }^{2}$ \\ Universitas Sriwijaya ${ }^{1,2}$ \\ listya_anisa@fe.unsri.ac.id ${ }^{1 *}$, ichsansiregar@fe.unsri.ac.id ${ }^{2}$
}

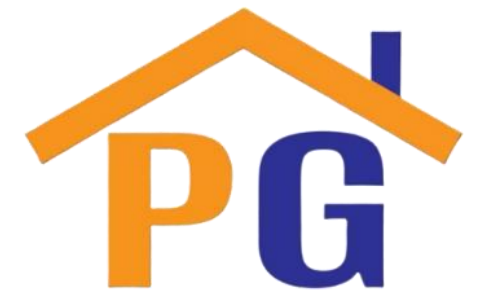

Riwayat Artikel

Diterima pada 24 Januari 2021

Revisi 1 pada 30 Januari 2021

Revisi 2 pada 6 Februari 2021

Disetujui pada 8 Februari 2021

\begin{abstract}
Purpose: This study aimed to analyze the effect of audit rotation and audit fee policy toward audit quality with lowballing audit practice as the intervening variable.
\end{abstract}

Research methodology: The research method used was path analysis with a sample of twenty manufacturing companies in Indonesia Stock Exchange during 2015-2019.

Results: The research results prove that the audit rotation and audit fee policy significantly affect the audit quality through the lowballing audit.

Limitations: The research sample used manufacturing companies listed on the IDX, so the generalization of this study's results for non-manufacturing and non-listed companies must be made carefully.

Contribution: This research can provide benefits for Audit Firms, regulators (PPPK), and professional associations (IAPI) as an evaluation of the implementation of audit rotation policies, implementation of regulations for determining audit fees following IAPI's Regulation No. 2 of 2016 concerning Determination of Financial Report Audit Service Fees, as well as evaluation of the implementation of the audit quality indicator guidelines formulated by IAPI.

Keywords: Audit rotation, Policy of determining audit fee, Lowballing audit, Negative abnormal audit fee, Audit quality

How to cite: Listya, A., \& Siregar, M. I. (2020). Audit rotation and audit fee determination policy on audit quality with lowballing audit practice as the intervening variable. Jurnal Akuntansi, Keuangan, dan Manajemen, 2(1), 71-82.

\section{Introduction}

The public accounting profession has an essential role in the business world, especially as an independent party with the competence and is trusted to provide assurance services. One of the services provided by a public accounting firm is a financial audit (general audit). The audit's objective is to increase the confidence of users of financial statements by gathering sufficient audit evidence to conclude whether the financial statements are prepared, in all material, following the reporting framework. Public accountants express an opinion that the financial statements are fairly presented, in all material respects, of the entity's financial position at the end of the period and its results and cash flows for that period (Arens, Elder, Beasley, 2015). Audits conducted by auditors are said to be of quality if they fulfill auditing standards and quality control standards (IAPI, 2011). From the auditor's point of view, an audit is considered qualified if the auditor carries out the audit in accordance with the Public Accountant's Professional Standards listed in the auditing standards, which include: professional qualities, independence of the auditor, the judgment used in the audit, and the preparation of the audit reports. Client confidence in audit firms and audit results will increase if the audit quality is good. Audit rotation regulations are aimed at maintaining the independence and ethics of public accountants and improving audit quality. The professional code of ethics for Public Accountants (IAPI, 2008) requires 
the rotation of engagement partners and audit firms personnel who are responsible for the engagement, for a predetermined period. It does not allow rotating personnel to be involved in the financial statement audit engagement until a certain period has passed since the last (cooling-off period) involvement.

The phenomenon that occurs related to the rotation policy is the audit firms that provide services to regulate the establishment of a new audit firms with a name change, changes in partner members and including leaving old partners, and appointing new partners to comply with audit rotation regulations. It is feared that it will create a moral hazard if there is no strict supervision from the regulator. Public Accounting Firms and Public Accountants (partners) that provide auditing services to issuers (companies listed on the IDX) are required to comply with the rotation regulations required to provide their services. Audit rotation regulations make competition between audit firms even tighter. Audit firms have to deal with this competition by implementing reducing/discounting the audit fee (lowballing audit), especially during the initial assignment/first year of service provision. This condition indicates that the audit fee's determination is carried out subjectively, meaning that it is determined by one or based on the bargaining power between the auditor and the client (Suharli and Nurlaelah, 2008). Lowballing is characterized by an initial price structure that is less than the total cost and can increase according to audit tenure.

Audit as a commodity is a phenomenon in the accounting profession in America and in Indonesia. Symptoms or phenomena of audit as a commodity, among others: relatively low audit fees, so that practitioners reduce costs which result in decreased audit quality; the entity/client is only willing to pay a cheap audit fee because what matters to the client is cheap and fast fees; competition between colleagues who dare to slam the price; and practitioners complained about audit service tender practices, including the cancellation of the tender after the winner was announced. The survey shows that the average audit fee for public companies in the world in 2016 increased by 3.4\% (CFO, 2016). This is due to the implementation of IFRS and ISA in almost all countries make auditors make more effort to improve audit quality, so that audit fees also increase. However, in Indonesia, there was a trend decrease in the average audit fee for non-financial public companies in 2017 by $1 \%$ compared to 2016.

The decrease in the average audit fees indicates competition among audit firms in Indonesia to determine audit fees. The decrease in audit fees mainly occurred in the manufacturing industry. The manufacturing industry has quite complex characteristics because it carries out activities in stages, starting from raw material processing to finished products. The manufacturing industry has a very diverse sub-sector. Generally, it requires specialist auditor expertise who usually provides better audit services at a higher cost than non-specialist auditors. If seen from the decrease in the average audit fee that occurs, this indicates that public accounting firms that provide audit services in the manufacturing industry offer audit fees below the normal audit fee. In the end, there was a concern over the determination of an audit fee ostensibly controlled by price competition and does not represent audit quality, but in order to gain a broad market share. Intense competition in the manufacturing industry and demands on management to increase stock market value have encouraged management to practice earnings management. Competition for audit services can cause a decrease in audit quality because auditors do not report or cannot detect earning management, because audit firms do not want to lose clients and reduce the quality of the audit. Offering audit fees below normal (lowballing) results in auditors reducing audit procedures to meet the audit fee budget, so that they may not detect earnings management.

The lowballing audit phenomenon is also related to audit rotation and audit fees, where the payment of fees for changes in auditors significantly reduces audit costs in the year after auditor changes (Sewon and Wang, 2012). Suppose the audit firms implement a high discount rate strategy (lowballing strategy). In that case, the audit firms' quality is likely low because the audit firms will reduce the audit procedures carried out to meet the low budget because of the discount. According to Bleibtreu and Stefani (2013), audit firms implementing a high discount rate strategy (lowballing strategy) will increase audit quality. As the engagement continues, many auditors increase their fees during subsequent periods due to increased effort in conducting audits and limited resources (Ettredge et.al, 2014).

The research question answered in this study: "How is the effect of audit rotation and audit fee determination policy on audit quality with lowballing audit practices as an intervening variable?" This research is expected to complete previous studies and provide benefits to various parties, such as (1) Public Accountant Firms (Audit Firms) and Public Accountants, the result of this study is expected as 
an evaluation of the impact of audit rotation, audit fee determination policy, and lowballing audit practice that affect audit quality; (2) PPPK (regulator), the result of this study is expected as an evaluation of the implementation of audit rotation regulatory policies and input to formulate regulations for public accounting firms in Indonesia in order to improve audit quality; (3) IAPI (professional association), the result of this study is expected as an evaluation of the implementation of IAPI's policy on the determination of audit fees; and (4) Academics; the result of this study is expected as a reference in auditing especially about the factors that affect audit quality.

\section{Literature review and hypothesis development}

\subsection{Literature review}

Several previous studies on audit turnover have had mixed results. Al-Khoury, et. al (2015) revealed a significant positive relationship between auditor independence and the auditor-client relationship and mandatory rotation. Ahmed (2014) reveals that auditors' mandatory rotation has a positive effect on the quality of the audit, adverse effects on the client's specific knowledge, and positive impacts on the auditor's independence. Research by Daugherty (2013) states that partners consider rotation to affect audit quality directly. Rotation is seen as an increase in independence so that it has a positive impact on audit quality. However, reduced client-specific knowledge has a negative impact on audit quality. Mgbame, et al (2012) also stated that there is a statistically significant relationship between mandatory rotation of public accounting firms and the quality of audits associated with audited reports. From the perspective of economic benefits, long-term audit work will establish an intimate and loyal relationship between auditors and clients. This will reduce the objectivity of the audit and reduce the independence of the auditor. The issue to be considered is that if the current auditor position is retained for a long time in the future, the auditor may feel very comfortable, which will disrupt the objectivity of the audit (Mautz and Sharaf, 1961).

However, some research results related to audit rotation are contrary. Onwuchekwa et al. (2012) pointed out that there is a negative correlation between mandatory audit rotation and audit quality. According to Kwon, Lim, and Simnett (2010), mandatory audit company rotation increases audit companies and customers' cost, but has no apparent positive impact on audit quality. After the introduction of firm audit rotation, the audit quality has not changed. Results of Fitriany et al. (2015) proved that the length of audit time did not affect audit quality in the period before supervision. However, from a neutral point of view, there is a convex and concave relationship between audit time and audit quality after the supervision period. The study also found that, the rotation of accounting firms does not affect audit quality. Two of the eight regression equations indicate that audit rotation will reduce audit quality before and after supervision. Specialization has a positive impact on audit quality. The obligation to perform audit rotation is not sufficient to improve audit quality.

The expectation theory put forward by Victor H. Vroom (1964) points out that the power to motivate a person to engage in work actively depends on the need and need for the interrelationship of the work result. The professional choice is related to motivation theory, that is, expectation theory. Expectation theory is the intensity of a tendency to act in a certain way, which depends on the intensity of the expectation that the action will be followed by specific outputs, and depends on the human attraction's output. The theory of motivation also means encouragement, a reason to do something, or behavior in order to achieve goals. The auditor's motivation factor is one of the important elements in an audit engagement. Motivation arises because the auditors feel confident that they can carry out the audit and customer demand and commercial needs. The audit quality will be high if the wishes and needs of the auditors that make their work motivation can be met. Compensation from the organization in the form of rewards according to the profession will lead to audit quality because auditors feel that audit firms have paid attention to their work's needs and expectations. The audit fee is one of the factors that motivate the auditors to implement his job. The client's financial condition influences the auditor's ability to cope with client pressure and intervention. A strong client's financial condition can provide a high audit fee and provide good auditors' good audit facilities. The fees given by clients aim to provide enthusiasm or motivation to auditors to be able to carry out audit tasks seriously and efficiently.

Studies of low-budget auditing practices in several countries have shown different results. Sepponen (2015) of the American Public Company shows that from the initial appointment to the third year of appointment, the audit fee of the auditor's turnover has been increasing, and in the third year of 
appointment, the level of audit fee has exceeded the previous level. When the company changed from a non-big four auditor to a big four auditor, the low ball effect was found to be the most obvious. Fitriany et.al. (2008) showed that lower than normal audit fees (negative abnormal audit fees/discounts) can still improve audit quality. This may be because the mandatory rotation of accountants and audit firms implemented in Indonesia since 2008 has increased competition in the audit market, which has resulted in strong bargaining power for clients, resulting in lower than normal fees. In the case of fierce competition in the audit market and high litigation and supervision risks, negative abnormal audit fees will not reduce audit quality but improve audit quality. This is because auditors want to protect their reputation and avoid litigation. Asthana and Boone (2012) pointed out that abnormal audit fees, whether the fees paid are too low or the fees paid, are higher than normal fees, which negatively impact audit quality.

According to Bleibtreu and Stefani (2013), only when audit firms try to regain their clients as quickly as possible, in other words, if they use lowball strategies for clients, they cannot professionalize audit firms well (ie, if the discount rate is very high). Otherwise, the audit company must have enough patience to wait for the competitor's maximum period to expire. Due to the implementation of external rotation, the audit quality is expected to decline. From previous studies, there are various research results regarding the pros and cons of audit rotation (audit firms and partners), various factors that underlie audit firms in determining audit fees, and the pros and cons of lowballing audit practices on audit quality in Indonesia and in other countries. Previous studies eventually became the basis for further research on the effectiveness of the implementation of audit rotation regulations, audit fee determination policies, analysis of lowballing audit practices, and audit quality measurement of public accounting firms listed in providing audit services in the capital market. Our research has determined the extent to which audit rotation and audit fee determination policies directly or indirectly affect the level of discretionary accruals (the level representing audit quality) under the intermediary of lowballing audit practices. This research aims to expand the previous research conducted by Fitriany et al. (2008), Fitriany et al. (2015), and Bleibtreu and Ulrike (2013), focusing on manufacturing companies on the Indonesian Stock Exchange (IDX).

\subsection{Hypothesis development}

2.2.1. The effect of audit rotation on lowballing audit and the effect of audit rotation on audit quality

Based on Fitriany et al. (2015), the test results proved that the length of the audit time had no effect on the audit quality in the period before supervision. However, from a neutral perspective to timeliness, the audit time has a convex relationship with the audit quality after the supervision period. The study also found that, generally speaking, public accountant rotation does not affect audit quality. Specialization has a positive impact on audit quality. The obligation to perform audit rotation is not sufficient to improve audit quality. Daugherty (2013) found that rotation is believed to increase independence and positively impact audit quality. Compulsory partner rotation allows auditors to have a new understanding of customer risks and participation issues, which in turn will increase the auditor's independence, even at the cost of losing knowledge of new partners, because new partners do not have the same expert knowledge of customers and old partners.

The results of Bleibtreu and Ulrike's (2013) show that mandatory auditor rotation will reduce the audit firm's profit contribution from clients that the audit firm has well understood. Audit rotation can only improve audit quality when the company tries to attract customers as quickly as possible, that is, when customers adopt a low-key strategy (that is, grant high discount rates) to customers. On the other hand, if the audit company is patient enough to wait for the competitor's maximum deadline to expire, the audit quality is expected to decline due to the implementation of external rotation. The determination of client audit fees is a controversial factor among public accounting practitioners. According to the research conducted by DeAngelo (1981b), the practice of low salary will not harm the independence of auditors, because this practice is closely related to the competitive response of independent auditors, and they expect that the increase in audit fees in the future will bring benefits (quasi rent in the future). It is not the result of the client's future economic benefits claimed by the public accountants of the regulatory agencies and professional regulatory agencies. In addition, according to Dan A. Simunic's research on big (Big Eight) and small (Non-Big Eight) accounting firms, it can be concluded that there is no proof that large accounting firms are auditing monopolistic practices are 
implemented in the market, and this is not the case. Facts have proved that there are significant differences between the audit fees of the Big Eight accounting firms and non-Big Eight accounting firms. The most important factor in determining an audit firm's audit fee is the consideration of the possibility of the audit firm's legal claims (litigation) (Mark H Taylor and Daniel T Simon, 1999).

\section{Ha1: Audit rotation has a positive effect on lowballing audit practices.} Ha4: Audit rotation has a positive effect on Audit Quality.

2.2.2. The effect of audit fee determination policy on lowballing audit and the effect of audit fee determination policy on audit quality

Yuniarti (2011) proved that audit costs have a significant impact on audit quality. Higher costs will improve the audit quality because the audit fees obtained within a year and the estimated operating costs required to perform the audit process can improve the quality of the audit. Gammal (2012) research proves that Lebanese multinational companies and banks tend to pay higher audit fees when looking for public accounting firms that can provide good audit reports and improve annual financial reports' credibility.

Members of public accounting firms must not attract customers by offering fees that may damage the industry's image and must not set contingent fees if the ruling reduces independence. However, in reality, audit companies provide audit services by reducing audit fees (offering audit discounts), especially in the process of starting to attract customers. Reducing audit costs may cause auditors to reduce some audit procedures to meet the discounted audit cost budget. There are at least two reasons that the audit fee discount may lead to a decrease in audit quality. First, lower than normal audit fees will create an economic bond between the auditor and the client. In this case, the auditor may inappropriately agree to the client's pressure (SEC, 1978; AICPA, 1978). Previous research has shown that low profile is merely a competitive response to the quasi-advantage of persistent participation (DeAngelo, 1981). DeAngelo (1981) believes that low profile is not an illegal act that infringes on auditors' independence because it will cause sunk costs, but the quasi-rents earned by current auditors instead of relying on discounts on initial costs. However, although economic theory suggests that sunk costs are unnecessary, research shows that sunk costs are not ignored and often significantly impact behavior (eg, Arkes and Blumer, 1985).

\section{Ha2: Audit Fee Determination Policy has a positive effect on lowballing audit practices. Ha3: Audit Rotation and Audit Fee Determination Policy have a positive effect on lowballing audit. \\ Ha5: Audit Fee Determination Policy has a positive effect on Audit Quality.}

\subsubsection{The effect of lowballing audit on audit quality}

Choi (2012) states that when the audit fee is below normal (negative abnormal audit fees), there are three possibilities:

a. Under the pressure of customers to submit unqualified financial reports, auditors have little motivation to compromise audit quality (auditors tolerate client opportunistic earnings management actions). This is because the auditor's choice of unprofitable (or only marginally profitable customers) is not enough to cover the expected costs associated with non-conforming reports (increased litigation risk, reputation loss). Therefore, it is foreseeable that when audit fees are lower than normal levels, there is no correlation between abnormal audit fees and disposable accruals (audit quality), or if there is a correlation, the correlation is very weak.

b. Because reforms such as SOX increase auditors' supervision, auditors may not have the incentive to weaken independence. These reforms allow auditors to limit the amount of accruals that clients decide on their own. Therefore, it is foreseeable that customers with negative abnormal audit fees have a negative relationship between abnormal audit fees and disposable accruals. In other words, audit fees are positively related to audit quality.

c. When auditors are willing to charge high audit fees for future profitable business and are willing to bear low audit fees (therefore, the current abnormal audit fees are negative), customers can easily shake the auditor's pressure and let them generate biased financial report (the following customer wishes). 
Prior to this situation, discounted costs would undermine the independence of auditors. Therefore, in this study, it can be foreseen that there is a positive correlation between the customers whose abnormal audit fees are negative and the abnormal audit fees. In other words, audit fees are negatively related to audit quality. Based on these three possible relationships, for customers whose abnormal fees are negative, the impact of abnormal audit fees on disposable accruals (audit quality) can be positive, negative, or insignificant. In this study, it is expected that abnormal audit fees will have a positive impact on the direction of arbitrary accruals (audit quality).

Ha6: Lowballing audit (negative abnormal audit fees) has a positive effect on audit quality. Ha7: Audit Rotation and Audit Fee Determination Policy positively affect Audit Quality through the mediation of lowballing audit practices.

\section{Research methodology}

This research implemented the Explanatory Method and path analysis to test the research variables' effect and prove the formulated hypothesis. The research data uses secondary data from the Indonesian capital market website (Indonesia Stock Exchange), which is taken from the annual financial reports (annual reports) of manufacturing companies listed on the Indonesian Stock Exchange from 2015 to 2019. This study's population is a listed company on the Indonesian capital market, whose financial statements are audited by the Big Four and non-Big Four public accounting firms. The sample selection method is a purposeful sampling based on the following conditions:

1. Manufacturing companies on the Indonesia Stock Exchange during the period 2015-2019. The method for separating normal from abnormal accrual level proxies is less appropriate if applied to non-manufacturing companies because they have different characteristics.

2. Observe the need to start disclosing (voluntary) audit fee information in the company's annual report.

3. Have complete data, including data on net income, net operating cash flow, total assets, total income, the net value of receivables, gross value of fixed assets, factual audit fees, business segments, geographical segments, inventories, number of employees, debts, audit reports, and listed shares.

4. Not delisting or stopping operations during the observation period. The financial statements are presented in Indonesian Rupiah.

Companies that meet the criteria and are used as research samples are twenty companies with the observation period of 2015-2019. Data collection is obtained from the Indonesia Stock Exchange (IDX) website, www.idx.co.id, to obtain annual reports and audited annual financial reports of companies, as well as a summary of the performance of listed companies (Indonesian Capital Market Directory) in the sector manufacturers listed on the IDX in 2015-2019. These reports contain information on audit firms and public accountants that provide audit services, audit fees (audit fees / professional service fees), and data related to audit quality variables (discretionary accruals).

\section{Table 1. Research Variables}

\begin{tabular}{|l|l|l|}
\hline \multicolumn{1}{|c|}{ Variable/Symbol } & \multicolumn{1}{|c|}{ Definiton } & \multicolumn{1}{c|}{ Measurement } \\
\hline $\begin{array}{l}\text { Exogenous Variable (X1): } \\
\text { Audit Firm Rotation }\end{array}$ & $\begin{array}{l}\text { The mechanism for the } \\
\text { periodic turnover (rotation } \\
\text { of the Public Accounting } \\
\text { Firm) }\end{array}$ & $\begin{array}{l}\text { Dummy variable: 1 if there is a } \\
\text { rotation of the public accounting } \\
\text { firm during the observation period; } \\
\text { and 0 otherwise }\end{array}$ \\
\hline $\begin{array}{l}\text { Exogenous Variable (X2): } \\
\text { audit fee determination } \\
\text { policies }\end{array}$ & $\begin{array}{l}\text { Some factors used by audit } \\
\text { firm for determining audit } \\
\text { fees (size of audit firm and } \\
\text { size of company) }\end{array}$ & $\begin{array}{l}\text { Dummy variable: 1 if the company } \\
\text { is audited by Big Four Public } \\
\text { Accountant Firm, and 0 if otherwise }\end{array}$ \\
$\begin{array}{l}\text { Size = logarithm natural (ln) of } \\
\text { company total assets at the end of } \\
\text { period. }\end{array}$ \\
\hline
\end{tabular}




\begin{tabular}{|l|l|l|}
\hline $\begin{array}{l}\text { Intervening Variable } \\
\text { (Y1): Lowballing Audit }\end{array}$ & $\begin{array}{l}\text { Practice where audit firm } \\
\text { offers an audit fee that is } \\
\text { lower than the existing } \\
\text { market price }\end{array}$ & $\begin{array}{l}\text { Proxied by negative abnormal audit fee } \\
\text { which is calculated from the difference } \\
\text { between the logarithm natural (ln) of } \\
\text { the factual audit fee and the normal } \\
\text { audit fee }\end{array}$ \\
\hline $\begin{array}{l}\text { Endogenous Variable (Y2): } \\
\text { Audit Quality (ABSDAC) }\end{array}$ & $\begin{array}{l}\text { The quality of the audit results } \\
\text { as measured by the ability to } \\
\text { detect earnings management }\end{array}$ & $\begin{array}{l}\text { Discretionary accrual, } \\
\text { Dait = ACCRit - NDAit }\end{array}$ \\
\hline
\end{tabular}

The model for abnormal audit fees is as follows:

$A F E E=\beta_{0}+\beta_{1} L N T A+\beta_{2} N B S+\beta_{3} N G S+\beta_{4} I N V R E C+\beta_{5} E M P L O Y+\beta_{6} L O S S L A G+\beta_{7} L E V E+\beta_{8} R O A$

$$
+\beta_{9} L I Q U I D+\beta_{10} B I G 4+\beta_{10} S H O R T_{-} T E N+\beta_{10} B T M+\beta_{11} \text { CHGSALE }+\varepsilon
$$

Data analysis with path analysis, the research hypothesis was tested with the Structural Equation Model (SEM). The test equipment used IBM SPSS Statistics 23.

$$
\begin{aligned}
& \mathrm{Y}_{1}=\rho \mathrm{X} 1 \mathrm{Y}_{1} \mathrm{X}_{1}+\rho \mathrm{X} 2 \mathrm{Y}_{1} \mathrm{X}_{2}+\rho \varepsilon 1 \mathrm{Y} 1 \\
& \mathrm{Y}_{2}=\rho \mathrm{X} 1 \mathrm{Y}_{2} \mathrm{X}_{1}+\rho \mathrm{X} 2 \mathrm{Y}_{2} \mathrm{X}_{2}+\rho \mathrm{Y} 1 \mathrm{Y}_{2} \mathrm{Y}_{1}+\rho \varepsilon 2 \mathrm{Y}
\end{aligned}
$$

This research also used the Sobel test to determine whether the relationship through an intervening variable is significantly capable of acting as a mediator in the relationship. The Sobel test was carried out by testing the strength of the indirect effect of exogenous variables, namely audit rotation regulation (X1) and audit fee policy (X2) on endogenous variables, namely audit quality (Y2), through the mediating variable of lowballing audit practices (Y1).

\begin{tabular}{|c|c|c|c|c|}
\hline Model & Koefisien Jalur & t & p & $\mathbf{R}^{2}$ \\
\hline \multicolumn{5}{|c|}{ Sub structural $1\left(\mathbf{X}_{1} \mathbf{X}_{2}\right.$ ke $\left.\mathbf{Y}_{1}\right)$} \\
\hline $\mathrm{X}_{1}\left(\rho \mathrm{X}_{1} \mathrm{Y}_{1}\right)$ & 0.488 & 3.273 & 0.002 & \multirow{2}{*}{0.263} \\
\hline $\mathrm{X}_{2}\left(\rho \mathrm{X}_{2} \mathrm{Y}_{1}\right)$ & 0.128 & 0.858 & 0.397 & \\
\hline \multicolumn{5}{|c|}{ Sub structural $2\left(X_{1} X_{2} Y_{1}\right.$ ke $\left.Y_{2}\right)$} \\
\hline $\mathrm{X}_{1}\left(\rho \mathrm{X}_{1} \mathrm{Y}_{2}\right)$ & 0.367 & 3.116 & 0.004 & \multirow{3}{*}{0.644} \\
\hline $\mathrm{X}_{2}\left(\rho \mathrm{X}_{2} \mathrm{Y}_{2}\right)$ & 0.529 & 5.066 & 0.000 & \\
\hline $\mathrm{Y}_{1}\left(\rho \mathrm{Y}_{1} \mathrm{Y}_{2}\right)$ & 0.142 & 1.234 & 0.226 & \\
\hline
\end{tabular}

\section{Results and discussion}

Table 2. Summary of the estimation results of model parameters

\subsection{The effect of audit rotation regulations on lowballing audit}

Testing the research hypothesis shows that audit rotation has a significant effect on lowballing audits with a positive relationship. This shows that in manufacturing companies, audit rotation regulations create practice lowballing audit, where audit firm performs lowballing audit (audit fees are below normal). This indicates that the practice of lowballing has become a common practice among audit firms to retain clients. Audit rotation will increase the audit firm's profit contribution because the 
audit firm can ask for a competitive fee because the client loses audit firm on the audit rotation rules. Audit firm will use the lowballing strategy when the client negotiates the audit offer. The results are consistent with Ottaway (2013) that with audit rotation, the practice of lowballing audit will become common and the tenure period will be shorter. Audit rotation will decrease the audit firm's profit contribution for clients who need specialist audits while clients who do not need specialist auditors.

\subsection{The effect of audit rotation on audit quality}

The results of testing the research hypothesis show that turnover significantly affects the audit quality with a positive relationship. Regulation of turnover increases the auditor's accountability by providing good ability to limit earnings management actions taken by the client company's management, resulting in better audit quality. The audit rotation improves the audit quality only if the company tries to win back customers as quickly as possible, that is, if they use a strategy of reducing risk to customers (that is, giving high discount rates). If, on the other hand, audit firms are patient enough to wait until the maximum duration of their competitors expires, the quality of the audit is expected to decline due to the implementation of external rotation.

The determination of the audit fee for clients is a controversial factor among public accounting practitioners. Audit rotation is one of the solutions in overcoming the problem of auditor independence because the application of audit rotation is intended to maintain audit quality because it can prevent a decrease in auditor independence. The existence of mandatory audit rotation in Indonesia can negate the effect of audit tenure on audit quality. The audit engagement period limitation can prevent emotional closeness between the auditor and the client due to the long engagement period, so that the auditor's independence will be maintained.

In fact, audit firms and public accountants can still audit the same client by not violating government regulations. Basically, audit firms do not want to lose customers because they do not want to lose audit fees due to their professional work. The fake rotation of auditors (audit firms) shows that the audit firm's conditions are formally based on government regulations. The rotation of audit firms has caused the relationship between the audit firm and the client to be severed. In essence, the relationship between the audit firm and the client is still in progress. This study's results are consistent with the study of Said and Khasarmeh (2014) that there is a statistically significant relationship between audit rotation and audit quality. This is consistent with Mohamed and Hussein (2013), who pointed out that audit rotation is one of the solutions to overcome auditor independence, because the application of audit rotation aims to maintain audit quality. However, Barbadillo et al. (2007), audit rotation cannot increase the independence of auditors. Compared with audit rotation, maintaining the reputation of auditors can maintain the independence of auditors.

\subsection{The effect of audit fee determination policy on lowballing audit}

Based on the hypothesis testing, the result shows that the audit fee determination policy does not significantly affect the lowballing audit with a positive direction. This shows that even though in the IAPI regulations it has been stated that public accountants may not provide a discount at the beginning of the audit engagement to increase in subsequent years, however, in reality there are still many audit firms that provide audit services at a value below the normal fee. The audit fee policy based on company size and audit company size (big four and non-big four) will not affect the amount of audit discounts. The research results are consistent with Palmrose (1986), that is, there is no significant relationship between the policies for determining audit fees based on the Big Eight and non-Big Eight paradigms, but if it is based on the professional industry category, there will be low-price practices due to the reduction of audit fees at the beginning of the business.

\subsection{The effect of audit fee determination policy on audit quality}

The test results show that the audit fee determination policy significantly affects the audit quality in a positive relationship. Due to the existence of appropriate audit fee determination policies, audit firms and public accountants are encouraged to provide high-quality audit services. In fact, the audit company will still consider the company's size to determine the nature, extent and time of the audit task when determining the amount of audit fees for the client. For customers with complex business and strict regulations, audit fees are usually high. At the same time, the audit fees set by the 
Big Four accounting firms are higher than those of non-Big Four accounting firms. The results of the study are consistent with Sawan and Alsaqqa (2013), because the auditors of the Big Four companies are more independent than the auditors of non-Big Four companies. Big Four provide stronger and more effective reports to maintain a higher reputation and various income accounting scandals and litigation issues. Contrary to the research of Amake and Okafor (2012), audit fees and audit tenure policies have no significant impact on audit quality, because the inherent characteristics of audit practice may lead to a decline in auditor independence and a tendency to use more auditors. Personal service and close relationship with customers.

\subsection{The effect of audit rotation and audit fee determination policy on lowballing audit}

From the perspective of research model testing, audit rotation and audit fee determination strategies together significantly affect lowballing audits in a positive relationship. The existence of audit rotation promotes competition in the audit service market. Therefore, audit companies provide discounts at the beginning of the business to maintain new customers' audit continuity.

\subsection{The effect of lowballing audit on audit quality}

The test results show that the lowballing audit has no significant impact on the audit quality in the positive relationship direction. This means that the auditor's abnormal audit fees cannot determine the audit quality level. The results of descriptive statistics show that most of the sample companies paid audit fees close to the normal fees that should have been paid, and some paid above normal fees. This can explain that lowballing audit (negative abnormal audit fee) does not significantly affect audit quality. Abnormal audit fees that do not significantly affect the audit quality can also be caused the auditors in carrying out the audit to have a professional attitude and comply with applicable standards. Professional auditors who comply with applicable standards will maintain their independence during the audit process without being affected by the receipt of audit fees that are lower or higher than normal fees. The audit quality is maintained.

The results of this study support the research of De Angelo (1981) that discounted fees at the beginning of the engagement (lowballing) does not affect auditor independency. Lowballing practice is an acceptable practice in auditing (Myers, et.al, 2003). Lee and Gu (1998) show that lowballing can improve audit quality. This matter, contrary to the SEC and the Cohen Report, argue that lowballing harms auditor independence. Lowballing is said to have negative consequences (Magee and Tseng 1990 in Fatemi, 2013; Dopuch and King, 1996) because auditors have a financial attachment to clients, so the practice of lowballing might damage the ability of auditors to be independent of managers (Fatemi, 2013). Public disclosure of audit fees will improve audit quality because it will strengthen auditor independency (Craswell and Francis, 1999). However, in Indonesia not all audit fees are disclosed to the public, so it is found that lowballing audits do not significantly affect audit quality.

\subsection{The effect of audit rotation and audit fee determination policy on audit quality through lowballing audit as intervening variable}

The test results show that the Audit Rotation and the Audit Fee Determination Policy significantly affect the Audit Quality by mediating lowballing audit practices with a positive relationship direction. The existence of rotation regulations and audit fee policy makes audit firms and public servants comply with regulations that encourage audit firms to provide quality audits. The practice of lowballing audit as mediation can affect audit quality on the premise that even the audit fee is below normal but audit firm must remain competitive and maintain audit quality. The results showed that the fee discount at the beginning of the engagement (lowballing) did not affect auditor independence. Lowballing is an acceptable practice in the audit.

\section{Conclusion}

Based on the results of the research that has been done, it can be concluded that:

a. Audit rotation causes competition and market competition for audit services, which can be seen from a decrease in audit costs. Audit firms provide audit fee discounts or submits below-normal audit fees at the beginning of the engagement to get clients.

b. Company size and audit firm size are not always the basis for audit firm and public accountant in determining audit fees. The audit fees and discounts that will be given to the client for the 
initial audit engagement can be through negotiations or considering quasi economic rent in the next engagement period.

c. Audit rotation and the Audit Fee Determination Policy together significantly affect the lowballing audit, indicating that audit firm and public accountant are trying to fulfill regulatory requirements while expanding audit services with a strategy of reducing audit costs and gradually increasing audit fees in the following engagement years.

d. The audit rotation significantly affects the quality of the audit with a positive relationship direction, indicating that with the audit rotation regulation, the audit quality will be maintained. This is indicated by the auditor's ability to detect discretionary accruals (earnings management) by management.

e. The Audit Fee Determination Policy significantly affects audit quality, indicating that a policy's existence to determine audit fees from professional associations can direct audit firm and public accountant to offer adequate audit fees and do not damage independency.

f. Lowballing Audit does not significantly affect audit quality, indicating that lowballing audits are a common practice in audit firm's efforts to retain its clients and do not damage independency.

g. Audit rotation and the Audit Fee Determination Policy together significantly affect audit quality by mediating the practice of lowballing audits, showing that audit lowballing is a strategy that is quite appropriate for audit firm in anticipating the need for audit rotation regulations while fulfilling compliance in determining the amount of service fees audit so that the expected audit quality can be achieved).

\section{Limitations}

Some limitations of the study and suggestions for future research:

a. This study uses discretionary accruals as a proxy for audit quality. Further research can use other audit quality proxies such as the Audit Quality Metric Score (AQMS), regulatory sanctions against auditors, restatements, peer review results and others.

b. Measuring abnormal audit fees with the audit fee estimation model, there is still a possibility of a misstatement model because of the endogeneity and correlated omitted variables. For further research, the audit fee estimation model is re-evaluated with the appropriate variables.

c. The research sample used manufacturing companies listed on the IDX. So the generalization of the results of this study for non-manufacturing and non-listed companies must be done carefully. Further research can try to find data on non-manufacturing and non-listed companies.

\section{References}

Ahmed, Anis. (2014). Auditors' perceptions of audit firm rotation impact on audit quality in Egypt. Accounting \& Taxation, 6(1), 105-120.

Al-Khoury, et.al. (2015). Auditor independence and mandatory auditor rotation in Jordan. International Business Research, 8(4). DOI: 10.5539/ibr.v8n4p73.

Amake, C.C. and Okafor, Chinwuba. (2012). Auditors independence, auditors' tenure and audit firm size in Nigeria. Research Journal of Finance and Accounting, 3(10).

Arens, A. A., R. J. Elder, dan M. S. Beasley. (2015). Auditing dan jasa assurance Edisi 15 Jilid 1: Pendekatan Terintegrasi. Erlangga.

Arkes, H. R., \& Blumer, C. (1985). The psychology of sunk cost. Organizational behavior and human decision processes, 35(1), 124-140.

Asthana, Sharad and Boone, Jeff P. (2012). Abnormal audit fee and audit quality. Auditing: A Journal of Practice \& Theory, SSRN: https://ssrn.com/abstract=2029172.

Barbadillo Ruiz, E, Carrera, N., Gómez-Aguilar, N., \& Humphrey, C. (2007). Mandatory audit firm rotation in Spain: a policy that was never applied. Accounting, Auditing \& Accountability Journal, 20(5), 671-701.

Bleibtreu, Christopher dan Ulrike Stefani. (2013). The effects of mandatory auditor rotation on low balling behavior and auditor independence, http://www.wiwi.unikonstanz.de/econdoc/working-paper- series/, Working Paper (Preliminary Version), September 2013. 
Choi, Jong-Hag, Chansog Kim, Jeong-Bon Kim, \& Yoonseok Zang. (2010). Audit office size, audit quality and audit pricing. Auditing: A Journal of Practice \& Theory American Accounting Association, 29(1). Doi: 10.2308/Aud.2010.29.1.73 pp.73-97.

Choi, J. H., Kim, J. B., Liu, X., and Simunic, D. A. (2008). Audit pricing, legal liability regimes, and Big 4 premiums: Theory and cross-country evidence. Contemporary Accounting Research, 25(1), 55-99.

Craswell A.T. and Francis J.R., (1999). Pricing initial audit engagements: a test of competing theories. The Accounting Review, 74(2), 201-216. American Accounting Association.

Daugherty, B., Dickins, D., \& Higgs, J. (2010). Audit partner rotation: An analysis of benefits and costs: Working paper. University of Wisconsin-Milwaukee.

Daugherty, B. E., Dickins, D., Hatfield, R. C., \& Higgs, J. L. (2012). An examination of partner perceptions of partner rotation: Direct and indirect consequences to audit quality. Auditing: A Journal of Practice \& Theory, 31(1), 97-114.

Daugherty, B. E., Dickins, D., Hatfield, R. C., \& Higgs, J. L. (2013). Mandatory Audit Partner Rotation: Perceptions of Audit Quality Consequences. Current Issues in Auditing, 7(1), 30-35.

DeAngelo, L. E. (1981a). Auditor size and audit quality. Journal of Accounting and Economics, 3(3), 183-199.

DeAngelo, L.E., (1981b). Auditor independence, 'low balling', and disclosure regulation. J. Account. Econ. 3 (2), 113-127.

Dopuch, N and King R. (1996). The effects of lowballing on audit quality: an experimental market study. Journal of Accounting, Auditing \& Finance. DOI:10.1177/0148558X9601100102.

Ettredge, Michael, Elizabeth Emeigh Fuerherm, Chan Li. (2014). Fee pressure and audit quality. Accounting, Organizations and Society, 39, 247-263.

Fatemi, D. J. (2013). New evidence on an old question: does lowballing undermine auditors' independence or their clients' investment decisions?, American Accounting Association, 7(1).

Fitriany, Liswan Setiawan. (2011). Pengaruh Workload dan spesialisasi auditor terhadap kualitas audit dengan kualitas komite audit sebagai variabel pemoderasi. Jurnal Akuntansi dan Keuangan Indonesia, 8(1).

Fitriany, Siregar, S. V., \& Anggraita, V. (2008). Pengaruh positif dan negatif abnormal audit fee terhadap kualitas audit. Simposium Nasional Akuntansi (SNA) Medan XVIII.

Fitriany, Sidharta Utama, Dwi Martani, dan Hilda Rosietta. (2015). Pengaruh tenure, rotasi dan spesialisasi Kantor Akuntan Publik (KAP) terhadap kualitas audit: perbandingan sebelum dan sesudah regulasi rotasi KAP di Indonesia. Jurnal Akuntansi dan Keuangan, 17(1), Mei 2015, hlm. 12-27. ISSN 1411-0288 print/ ISSN 2338-8137 online. DOI: 10.9744/jak.17.1.12-27.

Gammal, Walid El. (2012). Determinants of Audit Fees: Evidence from Lebanon. International Business Research, 5(11). ISSN 1913-9004 E-ISSN 1913-9012 Published by Canadian Center of Science and Education.

Institut Akuntan Publik Indonesia. (2016a). Panduan indikator kualitas audit pada KAP.

Institut Akuntan Publik Indonesia. (2016b). Peraturan pengurus IAPI No. 2 tahun 2106.

Institut Akuntan Publik Indonesia. (2011). Standar profesional akuntan publik. Salemba Empat.

Institut Akuntan Publik Indonesia. (2008). Kode etik profesi akuntan Publik. Salemba Empat.

Kwon S. D., Y.D. Lim and R. Simnett. (2014). The effect of mandatory audit firm rotation on audit quality and audit fees: empirical evidence from the Korean audit market. Auditing: A Journal of Practice \& Theory, 33(4):167-196. DOI: 10.2308/ajpt-50814.

Lee and Gu. (1998). Low balling, legal liability and auditor independence. The Accounting Review, 73(4), 533-555.

Mautz, R.K. and H.A. Sharaf. (1961). The philosophy of auditing. Sarasota, Florida: American Accounting Association.

Mgbame, C. O., Eragbhe, E., \&Osazuwa, N. P. (2012). Audit partner tenure and audit quality: An empirical analysis. European Journal of Business and Management, 4(7), 154-162.

Mohamed, Diana Mostafa and Hussien. (2013). Audit quality and the mandatory auditor rotation in Egypt", education, business and society. Contemporary Middle Eastern Issues, 6(2), 116-144.

Myers, James N, Linda A Myers, and Thomas C. Omer. (2003). Exploring the term of the auditorclient relationship and the quality of earnings: a case for mandatory auditor rotation?", The Accounting Review, 78(3), 779-799. 
Onwuchekwa, Erah, D., \& Izedonmi, F. I. (2012). Mandatory audit rotation and audit independence. Survey of Southern Nigeria, 3

Ottaway, Joanne. (2013). Improving auditor independence in Australia: is mandatory audit firm rotation the best option?

Palmrose, Zv. (1986). Audit Fees And Auditor Size - Further Evidence. Journal of Accounting Research, 24(1), 97-110.

Said, K., \& Khasharmeh, H. (2014). Auditors' perceptions on impact of mandatory audit firm rotation on auditor independence - Evidence from Bahrain. Journal of Accounting and Taxation, 6(1), $1-18$.

Sawan, N and Alsaqqa, I (2013). Audit firm size and quality: Does audit firm size influence audit quality in the Libyan oil industry? African Journal of Business Management, 7(3), 213-226. ISSN 1990-3839.

Sepponen, Laura. (2015). Audit pricing, lowballing and auditor changes: evidence from US Public Firms. Thesis.

Sewon O \& Kun Wang, (2012). Competition and low- balling: evidence from Texas Municipalities, Texas Southern University.

Suharli. M dan Nurlaelah. (2008). Konsentrasi auditor dan penetapan audit fee: investigasi pada BUMN. Jurnal Akuntansi dan Auditing Indonesia, 12(2), 133 - 148.

Taylor, Mark, H; and Simon, Daniel, T. (1999). Determinants of Audit Fees: The Importance of Litigation, Disclosure and Regulatory Burdens in Audit Engagements in 20 Countries. The International Journal of Accounting; 34(3), 375-388; ISSN: 0020-7063.

Vroom, Victor. H. (1964). Work and motivation. San Francisco, CA: Jossey-Bass.

Yuniarti, R. (2011). Audit firm size, audit fee and audit quality. Journal of Global Management, 2 (1), 84-97. 